\title{
Seasonal distribution of coastal mesozooplankton community in relation to the environmental factors in Iskenderun Bay (north-east Levantine, Mediterranean Sea) - ERRATUM
}

T. TERBÍYÍK KURT AND S. POLAT ${ }^{1}$

doi:10.1017/So025315412001713, Published by Cambridge University Press, 18 December 2012 (online).

In some pages of the article, the name of one author is misspelled in the running head: SEVIN Polat should be corrected as SEVİM Polat.

First published online 19 March 2013

REFERENCE

Terbiyik Kurt T. and Polat S. (2012) Seasonal distribution of coastal mesozooplankton community in relation to the environmental factors in İskenderun Bay (north-east Levantine, Mediterranean Sea). Journal of the Marine Biological Association of the United Kingdom 93. doi:10.1017/ So025315412001713. 